\title{
VERSLUMO UGDYMO/SI GALIMYBĖS UNIVERSITETINĖSE STUDIJOSE
}

\author{
Živilè Labutè \\ Mykolo Romerio universiteto \\ Socialinių technologijų fakulteto \\ Edukologijos ir socialinio darbo institutas \\ Ateities g. 20, LT-08303 Vilnius, Lietuva \\ El. paštas: zivilelabute@gmail.com \\ Telefonas (+ 3706 6) 0312631 \\ Irena Žemaitaitytė \\ Mykolo Romerio universiteto \\ Socialinių technologijų fakulteto \\ Edukologijos ir socialinio darbo institutas \\ Ateities g. 20, LT-08303 Vilnius, Lietuva \\ El.paštas: irene@mruni.eu \\ Telefonas (+ 370 5) 2714713
}

Pateikta 2013 m. rugsejjo 9 d., parengta spausdinti 2014 m. gruodžio 10 d.

doi:10.13165/SMS-14-6-3-08

Anotacija. Nagrinejamas keturių vienų iš didžiausių Vilniaus universitetų: Mykolo Romerio universiteto (toliau MRU), Vilniaus universiteto (toliau VU), Vilniaus Gedimino technikos universiteto (toliau VGTU) ir Lietuvos edukologijos universiteto (toliau LEU) studentu verslumo ugdymo/si galimybès universitetinèse studijose.

Straipsnio tikslas - atskleisti studentu verslumo ugdymo/si galimybes universitetinèse studijose. 
Darbe taikyti šie tyrimo metodai: teorinis - mokslinès literatūros analizè, ES ir Lietuvos dokumentų, reglamentuojančiu verslumą, analizé; empirinis tyrimas - anketi$n \dot{e}$ studentu apklausa apie verslumo ugdymo/si galimybes universitetinése studijose bei aprašomojo pobūdžio statistinis metodas.

Išanalizuotas tyrimas atskleidè, kad visu keturiu universitetų: $M R U, V U, V G T U$ ir LEU studentu verslumo ir verslumo ugdymo samprata nesiskiria. Studentai pritaria tam, kad versluma aukštojoje mokykloje ugdyti reikia, tačiau nežino, ar ju universitete yra ugdomas verslumas. Studentai nesidomi ir nedalyvauja universiteto vykdomose veiklose, skirtose ugdyti versluma, nežino, ar patys yra verslūs. Studentai nežino, ar $i$ studiju programa yra įtrauktas verslumo ugdymas, ar ju universitete yra galimybe pasirinkti laisvai pasirenkama verslumo studiju dalyka. Studentu atsakymai parodé, kad jie sutiktu papildomai studijuoti versluma, tik pageidautų, jog būtu sudaryta galimybe patiems laisvai pasirinkti. Tyrimo rezultatai atkleide, kad labiausiai verslumas yra ugdomas MRU, kiek mažiau VU, dar mažiau VGTU ir mažiausiai LEU.

Reikšminiai žodžiai: verslumas, verslumo ugdymas, universitetinès studijos.

\section{Ivadas}

Žmogiškojo kapitalo teorijoje švietimas ir aukštasis mokslas yra įvardijamas kaip vienas iš svarbiausių faktorių, lemiančių ekonominị ir socialinị šalies stabilumą, visuomenès brandą, vertybių formavimąsi bei suteikiantis kur kas daugiau galimybių pačiam individui ${ }^{1}$. Tai suvokdamos didžiosios tarptautinès organizacijos, tarp jų ir Europos Sąjunga, dèmesị sutelkè ị mokslą, švietimą ir mokslinius tyrimus. Šiandieniniame pasaulyje, kuriame vis didèja konkurencija, sparčiai vystosi technologijos, švietimas igauna vis didesnę svarbą.

Lietuvos Valstybinès švietimo strategijoje 2003-2012 m. vienu iš svarbiausių prioritetu ịvardytas užimtumo skatinimas ir investicijos į žmogiškąji kapitalą ${ }^{2}$. Vienas iš užimtumo skatinimo elementų - verslumas. Kadangi gyvename žinių visuomenèje, nuolat besikeičiančioje technologinèje, ekonominejje ir politinèje aplinkoje, verslumas ir jo ugdymas itin svarbūs. Pirmiausia dèl to, kad „versli visuomenè užtikrina šalies ekonomikos augimą, darbo vietų kūrimą, tuo pačiu - tarptautinị šalies konkurencingumą “"3. Galiausiai, pats asmuo, turintis verslaus žmogaus savybių, leng-

1 Bagdonavičius, J. Žmogiškasis kapitalas: mokymo metodine priemone. Vilnius: VPU, 2002.

2 Lietuvos Respublikos Seimo nutarimas Nr. IX-1700 „Dèl valstybinès švietimo strategijos 2003-2012 metų nuostatų “ [interaktyvus]. [žiūrèta 2012-10-07]. <http://smm.lt/ti/docs/strategija2003-12.doc>.

3 Sodžiutè, L. Verslumo ugdymas aukštojo moklso sistemoje: taikomų metodų vertinimas bei Lietuvoje vykdomų verslumo projektų patirties apžvalga. Respublikinés mokslinés-praktinès konferencijos "Studijos besikeičiančioje verslo aplinkoje“ pranešimu medžiaga. Alytaus kolegija, Lietuvos ekonomikos dèstytojų asociacija LEDA [interaktyvus]. Vilnius: Ciklonas, 2009, p. 35 [žiūrèta 2013-11-03]. <http://leda.lt/studijos_besikeiciancioje_verslo_aplinkoje. pdf\#page $=35>$. 
vai integruosis ị darbo rinką bei puikiai mokès tvarkytis savo asmeninị gyvenimą. Todèl verslumas turi būti ugdomas visuose švietimo lygiuose.

Būtent aukštojo mokslo ir verslumo ugdymo/si svarba visuomeneje bei nuomone, jog tiek aukštasis mokslas, tiek verslumas užtikrina šalies ekonomikos augimą ir šalies konkurencingumą, yra grindžiamas temos aktualumas.

Lietuvos ir užsienio šalių tyrinètojai nagrinėja įvairius verslumo aspektus. Verslumo sampratos klausimai, versliam asmeniui reikalingos savybès ir gebejimai nagrinèti ịvairių užsienio autorių moksliniuose darbuose (L. G. Davies, A. A. Gibb; C. Turner; A. Fayolle, P. Kyro; J. Timmons, S. Spinelli ${ }^{4}$ ir kt.). Lietuvoje yra tyrinèta verslumo ir verslininkystès samprata ${ }^{5}$. Yra darbų, nagrinejjančių verslumo ugdymą aukštojoje mokykloje: P. Zakarevičiaus ir A. Župerkos straipsnis apie studentų verslumo ugdymą aukštosiose mokyklose ${ }^{6}$, A. Župerkos straipsnis apie studentų verslumo ugdymo plètrą Lietuvoje $e^{7}$. Šiuo tyrimu buvo siekiama sukurti verslumo ugdymo modelį, padedantị numatyti Lietuvos studentų verslumo ugdymo perspektyvines kryptis. Lietuvoje yra nagrinètas ir dėstytojų požiūris ị verslumą ir verslumo ugdymą. Tirtas studentų požiūris ị verslumą ${ }^{8}$, atlikta aukštųjų neuniversitetinių studijų verslumo ugdymo programų analizé $\dot{e}^{9}$, tirtas verslumo ugdymas profesiniame mokyme ${ }^{10}$. Tačiau Lietuvoje stinga darbų apie studentų verslumo ugdymo/si galimybes universitetinèse studijose.

Mokslinė problema: Šiuo metu Lietuvoje skiriama daug dėmesio verslumui. Verslus žmogus laikomas siekiamybe, praturtinančia visuomenę tiek ekonomiškai, tiek intelektualiai. Universitetai užima svarbią vietą visuomenèje ir yra institucija,

4 Davies, L. G., Gibb, A. A. Recent research in entrepreneurship.The Third International EIASM Workshop, Gower, 1991; Turner, C. Veskite i sèkmę. Kaip sukurti verslias organizacijas. BMI: Baltos lankos, 2005; Fayolle, A. Kyro, P. The Dynamics between entrepreneurship, environment and education, 2008; Timmons, J., Spinelli, S. New venture creation: Entrepreneurship for the 21st century, 2008.

5 Lydeka, Z. Verslininkas, verslumas ir verslininkystè. Organizacijų vadyba: sisteminiai tyrimai. (2). 1996, p. 137-147; Lydeka, Z. Verslumas ir verslininkystès sèkmè. Ekonomika. 2000, (52): 51-61.

6 Zakarevičius, P.; Župerka, A. Studentų verslumo ugdymas aukštosiose mokyklose. Organizaciju vadyba: sisteminiai tyrimai. 2011, p. 60.

7 Župerka, A. Studentų verslumo ugdymo plètrą Lietuvoje. Vadybos mokslas ir studijos - kaimo verslu ir ju infrastruktūros plètrai. 2011, 2 (26): 279-287.

8 Jelagaite, A. Vilniaus pedagoginio universiteto ekonomikos ir verslo pagrindų specialybès I kurso studentų požiūris ị verslumą tautinès ir europinès integracijos kontekste. Visuomenès darni pletra: problemos ir perspektyvos. Moksliniu straipsniu rinkinys: Ekonominès ir socialinès politikos studijos (V). Vilnius: Vilniaus pedagoginio universiteto leidykla, 2008.

9 Strazdienè, G.; Garalis, A. Verslumas: ugdymo programos ir jų efektyvumo raiška. Organizaciju vadyba: sisteminiai tyrimai [interaktyvus]. 2006, p. 153-168 [žiūrèta 2013-11-28]. <http:// archive.minfolit.lt/arch/5501/5651.pdf>.

10 Paulionienė, L. Verslumo ugdymas profesiniame mokyme. Profesinis rengimas: tyrimai ir realijos [interaktyvus]. 2007, 13: 200-211[žiūrèta 2013-11-28]. <http://esf.vdu.lt/esf/esf0013/downloads/16.pdf $>$. 
kurioje ruošiamas jaunimas - būsimos visuomenès ateitis. Tačiau problema yra ta, kad universitetai tik neseniai sutelkè dėmeși ị verslumo ugdymą, tai dar nauja ir neišplitę, tad neaišku, ar yra užtikrinama galimybė studentams ugdytis verslumą.

Tyrimo tikslas: atskleisti studentų verslumo ugdymo/si galimybes universitetinèse studijose.

\section{Tyrimo uždaviniai:}

1. Apibrèžti verslumo ir verslumo ugdymo sampratas.

2. Išanalizuoti verslumo ugdymo/si prielaidas universitete.

3. Atskleisti studentų požiūrị ị verslumo ugdymo/si galimybes universitete.

\section{Verslumo ir verslumo ugdymo sampratos}

Verslumo sąvoka yra labai plati ir daugelis autorių pateikia skirtingą šios sąvokos aiškinimą. Pati verslumo sąvoka yra kildinama iš angliško žodžio „entrepreneurship“, kuris siejamas su naujų galimybių atradimu, savirealizacija ir ekonominès ar socialinès naudos kūrimu. Kaip teigia C. Turner „verslumas - tai savanoriškas bendras darbas, rizikavimas, kūrimas, igyvendinimas, gebejjimas iškelti ir sẻkmingai diegti novatoriškas idejas, kuriomis siekiama kuo plačiau panaudoti galimybes neapsiribojant esamais moduliais, struktūra ir ištekliais" ${ }^{\text {"11 }}$. Prof. D. F. Kuratko verslumą ịvardija kaip „kompleksinị reiškinị, apimantị individų gebejjimus ir iniciatyvą patiems, grupèse, esamose arba naujose organizacijose, pastebèti bei kurti naujas ekonomines galimybes (naujus gaminius, gamybos metodus, organizavimo schemas ir gaminių-rinkų kombinacijas), generuoti bei igyvendinti savo idejjas rinkoje esant neapibrežtumo sąlygoms, priimant savarankiškus sprendimus dèl resursų, formos ir priemonių “12. Apibendrindami verslumo sąvokos sampratą P. Kaufmannas ir R. P. Dantas skiria tris pagrindines kryptis, verslumą siejant: 1. „su versliam asmeniui būdingomis savybèmis - tai kūrybingumas, gebejjimas spręsti problemas, gebejjimas priimti sprendimus, kritinis mąstymas, lyderystè, motyvacija, iniciatyvumas ir kt.; 2. su naujų įmonių kūrimu, naujų gaminių ịdiegimu; 3. su verslininko veikla"13. Anot Z. Lydekos „verslumas yra igimtos ir igytos žmogaus savybès, leidžiančios jam novatoriškai mąstyti ir aktyviai bei rizikingai veikti “" ${ }^{14}$. L. Gegeckienè ir A. Grikšienè skiria dvi verslumo sampratas. Pirmoji samprata, kad „verslumas - igimtos ir igytos žmogaus savybès, leidžiančios jam novatoriškai mąstyti ir aktyviai bei rizikingai veikti visose gyvenimo situacijose“ bei antroji samprata, kad „verslumas - tai siekimas nauju

11 Turner, C. Veskite i sèkmę. Kaip sukurti verslias organizacijas. BMI: Baltos lankos, 2005 iš Strazdienė G.; Garalis A. Verslumas: ugdymo programos ir jų efektyvumo raiška, supra note 9 , p. 154.

12 Kiškis, M.; Lunevičiūte, G. Verslumas elektroninèje erdvèje. Vilnius: MRU, 2011, p. 6.

13 Dudaitè, J.; Žibėnienè, G. Verslumo edukologijos studijų programą igyvendinančių dèstytojų samprata apie verslumą ir verslumo ugdymą. Socialinis darbas. 2012, 11 (1): 168. 
idejjų, projektų igyvendinimo, t. y. sugebëjimas sèkmingai organizuoti ir valdyti savo gyvenimą bei verslą, pelningai gaminti prekes ar teikti paslaugas. Tai mąstymas ir veikimas"15. Ekonominio raštingumo ir verslumo ugdymo $2004 \mathrm{~m}$. strategijoje verslumas apibrèžiamas kaip ,asmens mąstymo būdas ir asmeninès socialinès bei vadybinès kompetencijos, leidžiančios turimas žinias pritaikyti savo kasdieniam gyvenimui, t. y. konkretūs gebejjimai, teikiantys galimybę ne tik organizuoti savo verslą, bet ir prisiimti riziką už padarytus sprendimus" ${ }^{\text {"16 }}$. Nacionalinëje jaunimo verslumo ugdymo ir skatinimo 2008-2012 m. programoje jaunimo verslumas apibrěžiamas kaip ,jauno žmogaus požiūris, łgūdžiai ir žinios, kurie leidžia atpažinti galimybę kurti pridètinę vertę (tiek socialinę, tiek ekonominę), ir veiksmai, skirti šiai galimybei panaudoti “"17. Visos šios verslumo sampratos atskleidžia du požiūrius ị verslumą: siauresnį, teigiantị, kad verslumas - tai gebejimas sukurti verslą, jị vystyti ir jam vadovauti, bei platesni požiūrị, kad verslumas - tai tam tikrų asmens savybių rinkinys, pvz.; kūrybingumas, kritinis mąstymas, iniciatyvumas ir kt., reikalingas kasdieniniame gyvenime, ịvairiose gyvenimo situacijose.

Igimtą verslumą turi ne visi žmonès, verslumas pats savaime retai kada atsiranda, tad ji reikia ugdyti. G. Gormano, D. Hanlono ir W. Kingo nuomone, „verslumo galima išmokyti arba bent jau galima padrąsinti imtis verslo" ${ }^{18}$. M. Anselmo nuomone, „žmonès gimsta su polinkiu verslumui, bet verslumo lygis bus aukštesnis, jeigu jie bus mokomi verslumo gebejjimų “19. Pats „verslumo ugdymas apima žinias, igūdžių ugdymą, nuostatas ir asmenines savybes ${ }^{\text {"20 }}$. Verslumas yra ugdomas aktyvia ir savarankiška veikla, kuri skatina mąstyti ir veikti.

\section{Verslumo gebėjimų ugdymo/si prielaidos universitete}

\subsection{Aukštųjų mokyklų: MRU, VU, VGTU ir LEU studijų programų aprašų analizè}

Studiju krypties aprašai - vieni svarbiausių aukštojo mokslo sistemos dokumentų, kurių paskirtis, pasak P. McGhee, „nustatyti bendrus reikalavimus siekiant akademinių standartų $<\ldots . .>$, informuoti akademinę bendruomenę ir ypač programų

15 Gegeckienè, L.; Grikšienè, A. Verslumas: metodinè priemonè. Vilnius: Ciklonas, 2009, p. 15.

16 Ekonominio raštingumo ir verslumo ugdymo strategija, Nr. ISAK-835, 2004, p. 2.

17 Lietuvos Respublikos Vyriausybès nutarimas Nr. 339 „Dèl nacionalinès jaunimo verslumo ugdymo ir skatinimo 2008-2012 metų programos patvirtinimo" [interaktyvus]. 2008, Vilnius [žiūrèta 2013-10-31]. <http://www3.lrs.lt/pls/inter3/dokpaieska.showdoc_l?p_id=318306\&p_ query $=\& p \_t r 2=>$.

18 Solomon, G. The 2004-2005 national survey of entrepreneurship education in the United States, Italy: OECD, 2005, iš Strazdienè, G.; Garalis, A. supra note 9, p. 155.

19 Ibid., p. 155.

20 Lietuvos Respublikos Vyriausybès nutarimas Nr. 339 „Dèl nacionalinės jaunimo verslumo ugdymo ir skatinimo 2008-2012 metų programos patvirtinimo“, supra note 17. 
rengejejus, kokie studijų turinio elementai yra svarbiausi, kokių mokèjimų turi igyti studentai, kokie minimalūs ir tipiniai reikalavimai keliami studentų pasiekimams, bei paskatinti diskusijas, kaip juos tobulinti“ “21. Iš to matyti, kad studijų krypties aprašai turi tris tikslus: nustatyti bendrus reikalavimus, informuoti ir skatinti diskusijas. Aukštosios mokyklos studijų krypties aprašu remiasi norėdamos parengti naujas ar patobulinti jau esamas studijų programas. Parengdamos studijų krypties aprašus aukštosios mokyklos prisiima atsakomybę už studijų kokybę ir už aprašuose nurodytus reikalavimus aprašytoms kvalifikacijoms. Būtent studijų krypties aprašai - tai pagrindas, kuriuo remiantis yra rengiamos studijų programos.

Apibendrinant išanalizuotus aukštųjų mokyklų: MRU, VU, VGTU ir LEU studijų programų aprašus, galima daryti prielaidą, kad daugiausia dèmesio ị verslumo ugdymą yra sutelkęs MRU. Šio universiteto daugumos studijų programų turinys yra orientuotas ị verslumo ugdymą, yra sudaryta galimybė studentams laisvai pasirinkti verslumo ir savisamdos studijų dalyką. Atsižvelgiant ị tai, kad VU yra pats didžiausias universitetas ir $\mathfrak{i}$ tai, kad verslumo ugdymas yra ịtrauktas tik $\mathfrak{i}$ kelias bakalauro ir magistrantūros studijų programas, galima spręsti, kad šio universiteto studijų programos yra mažiausiai orientuotos ị verslumo ugdymą. VGTU ir LEU didelio dèmesio verslumo ugdymui neskiria, tačiau ị kai kurias bakalauro ir magistrantūros studiju programas verslumą įtraukè.

\subsection{Aukštųjų mokyklų: MRU, VU, VGTU ir LEU strateginių planų analizè}

Dèl padidejusio aplinkos nepastovumo universitetai yra priversti prisitaikyti prie visuomenejje vykstančiu pokyčių, todèl strateginis planavimas tampa labai svarbia tolesnès universitetų veiklos priemone. Strateginis planavimas - tai valdymo įrankis, kuris aukštajam mokslui buvo pritaikytas remiantis verslo praktika ${ }^{22}$. Strategini planavimą galima apibrèžti kaip procesą, kuris orientuojasi $\mathfrak{i}$ strateginius ir operacinius tikslus, strategijas ir siekus, grịstas organizacijos politika, veiklos būdais, programomis, kuriomis remiamasi siekiant institucijos tikslų, planuojamų rezultatų bei organizacijos efektyvumo ${ }^{23}$. Kiekvienas universitetas sudaro strateginius planus, kuriuose nustato svarbiausią universiteto veiklos misiją, viziją, pagrindinius universi-

21 McGhee, P. The Academic Quality Handbook: Enhancing Higher Education in Universities and Further Education Colleges. Routledge Falmer. Taylor and Francis Group, London and New York, 2004. Studijų krypčiu skirtingoms pakopoms kūrimo metodika [interaktyvus]. p. 15-16 [žiūrèta 2013-05-09]. <http://www.skvc.lt/files/SKAR/Rezultatai/metodika.pdf>.

22 Rowley, Lujan ir Dolence, 1997 iš Gerulaitis, D., et al. Strateginio planavimo ir universiteto valdymo kryptys: universiteto socialinių partnerių ir akademinès bendruomenès sutelktos grupès tyrimo rezultatai. Jaunųu mokslininku darbai [interaktyvus]. 2012, 1 (34) [žiūrèta 2013-1024]. <http://vddb.library.lt/fedora/get/LT-eLABa-0001:J.04 2012 ISSN_1648-8776.N_1_34. PG_94-100/DS.002.0.01.ARTIC>. 
teto tikslus, uždavinius, plètros kryptis bei perspektyvas planuojamam laikotarpiui. Apibendrinant išanalizuotus keturių didžiausių Vilniaus universitetų: MRU, VU, VGTU ir LEU strateginius veiklos planus matyti, kad visuose universitetuose verslumo ugdymui yra skiriamas nemažai dėmesio. Visų šių universitetų viena iš misijų, vizijų, uždavinių ar tikslų - verslios asmenybės ugdymas. Vadinasi, verslus žmogus visų šių universitetų siekiamybè.

\section{Verslumo ugdymo/si galimybių universitetete rezultatų analizė}

\subsection{Empirinio tyrimo metodologija}

Siekiant išsiaiškinti verslumo ugdymo/si galimybes MRU, VU, VGTU ir LEU buvo atliktas kiekybinis tyrimas. Kiekybinis tyrimas pasirinktas todèl, kad tiriama didelè, išmatuojama ir apskaičiuojama populiacija. Empirinis verslumo ugdymo/si galimybių MRU, VU, VGTU ir LEU tyrimas buvo atliktas 2013 m. gegužès-birželio mèn., pasitelkus kiekybinị duomenų rinkimo metodą - anketavimą. Tyrime iš viso dalyvavo 398 studentai iš keturių didžiausių Vilniaus universitetų: MRU, VU, VGTU ir LEU.

Kadangi tiriamų universitetų studentų skaičius gerokai skiriasi (MRU - 19 318, VU - 21562, VGTU - 3 073, LEU - 9008), taikyta sluoksninè imtis, kai imtis sudaroma iš kiekvienos grupès pagal proporcijas, atspindinčias realios populiacijos proporcijas. Todèl atlikti skaičiavimai parodè, kad kiekviename universitete reikia apklausti skirtingą skaičių studentų: MRU - 123, VU - 135, VGTU - 84, LEU - 56. Imtis parinkta atsitiktinai, t. y. visi populiacijos elementai turèjo vienodas galimybes patekti ị imtị. Vilniaus universitetuose studijuojantys studentai pasirinkti dèl patogiosios imties.

\subsection{Empirinio tyrimo rezultatų analizè}

Tyrimo duomenys atskleide், kad visų keturių universitetų: MRU, VU, VGTU ir LEU studentų dauguma (65\%) verslumą laiko ir igimta, ir igyta savybe. Verslumą studentai $(68,475 \%)$ sieja su gebejjimu įžvelgti galimybes. Studentai $(59,675 \%)$ verslumo ugdymą labiau sieja su vertybinių orientacijų, nuostatų, asmeninių savybių formavimu ir igūdžių lavinimu. Visų keturių universitetų dauguma studentų $(83,8$ \%) pritaria tam, kad verslumą aukštojoje mokykloje ugdyti reikia, tačiau nèra tikri $(39,725 \%)$, ar verslumas yra ugdomas jų studijuojamame universitete. Dauguma studentų nesidomi $(48,325 \%)$ ir nedalyvauja $(62,4 \%)$ universiteto vykdomose veiklose, skirtose ugdyti verslumą, bei nèra tikri (49,825 \%), ar jie patys yra verslūs. Didžioji dalis visų keturių universitetų studentų pritaria tam, kad verslumas yra ugdomas seminarų metu (50,625 \%), dalyvaujant specialiose su verslumu susijusiose paskaitose, konferencijose ar mokymuose $(90,425 \%)$, atliekant praktiką $(79,9 \%)$, dalyvaujant universiteto visuomenineje veikloje $(43,15 \%)$ bei dalyvaujant projektinèje veikloje 
(76,525 \%). MRU ir LEU didesnè dalis studentų (87,9\%) pritaria, jog paskaitų metu yra ugdomas verslumas, VU ir VGTU studentai, atvirkščiai, nèra tikri $(68,6 \%)$ arba linkę nepritarti (74,6 \%) tam. Dauguma studentų (40,95 \%) sutinka, kad jų universitetas bendradarbiauja su verslą skatinančiomis institucijomis bei organizuoja susitikimus su verslo atstovais (41\%), išskyrus LEU studentus, kurie nèra tikri (46,4 \%) dèl to. Dauguma visų keturių universitetų studentų nèra tikri (42,85\%), ar ị studijų programą yra įtrauktas verslumas. MRU $(38,2 \%)$ ir VU (45,2\%) didesnè dalis studentų nèra tikri, ar universiteto kūrybinè atmosfera ịkvepia juos vystyti verslo idẻjas. Tuo tarpu VGTU (54,8 \%) ir LEU (48,2 \%) studentai linkę nepritarti šiam teiginiui. MRU (52,9 \%) ir VU (51,9 \%) dauguma studentų linkę pritarti, kad studijos ugdo socialinius ir vadovavimo igūdžius, reikalingus verslininkams. Tuo tarpu VGTU $(33,3 \%)$ ir LEU (30,4 \%) didesnè dalis studentų nèra tikri dèl šio teiginio. Didesné dalis MRU studentų sutinka (35,8\%), VGTU - nèra tikri (35,7\%), VU - nesutinka $(28,1 \%)$, LEU - visiškai nesutinka (25 \%) su tuo, kad studijos suteikia žinių, reikalingų norint pradèti nuosavą verslą. Dauguma visų keturių universitetų studentų nèra tikri (37,975\%), ar universitete yra galimybė pasirinkti papildomą verslumo studijų dalyką. Didžioji dalis MRU (57,7 \%), VU (61,5\%) ir VGTU (54,8 \%) studentų pritaria tam, kad universitete yra visuomeninès veiklos, susijusios su verslumo ugdymu, LEU didesné dalis studentų (39,3\%) néra tikri dèl to. MRU (65\%) ir VU (68,9\%) didesné dalis studentų pritaria, jog universitetas rengia konferencijas ar mokymus, ugdančius verslumą, VGTU (44 \%) ir LEU $(55,4 \%)$ didžioji dalis studentų nèra tikri dèl to. Didžioji dalis MRU (60,2 \%) ir VU (65,2\%) studentų pritaria, kad universitetas vykdo su verslumu susijusius projektus, VGTU panaši studentų dalis ir sutinka (41,7\%), ir nèra tikri (40,5\%), LEU pusę apklaustų studentų (50 \%) nèra tikri dèl to. Dauguma visų keturių universitetų studentų nėra tikri (47,575\%), ar universitetas organizuoja praktikas, susijusias su verslumo skatinimu. Studentai (79,2\%) pritaria tam, kad studijų programoje turi būti galimybe pasirinkti papildomą verslumo kursą, tačiau nenori ar dar abejoja dèl to, kad jis būtų privalomas. Didžioji dalis studentų sutinka, jog yra pasirengę vieną semestrą papildomai studijuoti verslumo studijų dalyką, išskyrus VGTU studentus $(27,175 \%)$, kurie nèra tikri dèl to. Šie tyrimo rezultatai rodo tai, kad verslumas labiausiai yra ugdomas MRU ir VU, kiek mažiau VGTU ir mažiausiai - LEU. Pastarųjų dviejų universitetų - VGTU ir LEU studentai daugeliu klausimų neturi nuomonès, vadinasi, arba studentai pasyviai dalyvauja universiteto gyvenime, arba vyksta per menka komunikacija tarp universiteto ir studentų.

\section{Išvados}

1. Apibendrinant ịvairius verslumo apibrèžimus, išryškejja du požiūriai ị verslumą: tai siauresnis, kad verslumas - gebejjimas sukurti verslą, jị vystyti ir jam vadovauti, bei platesnis, kad verslumas - tai tam tikrų asmens savybių rinkinys, reikalingas kasdieniniame gyvenime, visose gyvenimo situacijose. Verslumo ugdymas aprepia asmens žinių, ịgūdžių, nuostatų bei asmeninių savybių ugdymą. 
2. Išnagrinèti aukštųjų mokyklų: MRU, VU, VGTU ir LEU studijų programų aprašai atskleide, kad daugiausia demesio verslumo ugdymui skiria MRU. Šio universiteto daugumos studijų programų turinys yra orientuotas ị verslumo ugdymą, yra sudaryta galimybè studentams laisvai pasirinkti verslumo ir savisamdos studijų dalyką.

Išnagrinèti šių universitetų strateginiai planai atskleidè, kad visuose universitetuose verslumo ugdymui yra skiriama nemažai dėmesio. Visų šių universitetų viena iš misijų, vizijų, uždavinių ar tikslų - verslios asmenybės ugdymas.

3. Dauguma MRU, VU, VGTU ir LEU studentų nežino, ar universitetas bendradarbiauja su verslu, ar organizuoja susitikimus su verslininkais, ar universiteto kūrybinè atmosfera įkvepia juos vystyti verslo idejjas, ar ị studijų programą yra ịtrauktas verslumo ugdymas. Šių universitetų studentai sutinka, kad universitete yra visuomeninės veiklos, susijusios su verslumo ugdymu, kad universitetas rengia konferencijas ar mokymus, ugdančius verslumą, vykdo su verslumu susijusius projektus.

Studentai nežino, ar jų universitete yra galimybė pasirinkti laisvai pasirenkamą verslumo studijų dalyką, tačiau sutiktų papildomai studijuoti verslumą, tik pageidautų, jog būtų sudaryta galimybė patiems laisvai pasirinkti.

\section{Literatūra}

Bagdonavičius, J. Žmogiškasis kapitalas: mokymo metodiné priemone. Vilnius: VPU, 2002.

Davies, L. G.; Gibb, A. A. Recent research in entrepreneurship. Gower, London, Proceedings of the 3rd International EIASM Workshop, 1991.

Dudaitè, J.; Žibènienè, G. Verslumo edukologijos studijų programą igyvendinančių desstytojų samprata apie verslumą ir verslumo ugdymą. Socialinis darbas. 2012, 11(1) Ekonominio raštingumo ir verslumo ugdymo strategija, patvirtinta Lietuvos Respublikos švietimo ir mokslo ministro 2004-06-02 ìsakymu Nr. ISAK-835.

Fayolle, A.; Kyro, P. The Dynamics between entrepreneurship, environment and education. JK: Edvard Elgar Pubishing Limited, 2008.

Gegeckienè, L.; Grikšienè, A. Verslumas: metodine priemone. Vilnius: Ciklonas, 2009.
Gerulaitis, D., et al. Strateginio planavimo ir universiteto valdymo kryptys: universiteto socialinių partnerių ir akademinès bendruomenès sutelktos grupés tyrimo rezultatai. Jaunuju mokslininku darbai [interaktyvus]. 2012, 1 (34) [žiūrèta 2013-10-24]. <http://vddb.library.lt/fedora/get/LTeLABa-0001:J.04 2012 ISSN_16488776.N_1_34.PG_94-100/DS.002.0.01. ARTIC>.

Jelagaitè, A.; Lukoševičius, V. Mokiniu verslumo ugdymas bendrojo ugdymo mokykloje: mokytoju požiūris [interaktyvus]. Vilnius: LEU, 2011 [žiūrèta 2013-11-04]. <http://www.biblioteka. vpu.lt/pedagogika/PDF/2011/104/104. pdf\#page $=86>$.

Kiškis, M.; Lunevičiūtè, G. Verslumas elektroninëje erdvejje. Vilnius: MRU, 2011.

Lietuvos Respublikos Seimo nutarimas Nr. IX-1700 „Dèl valstybinès švietimo strategijos 2003-2012 metų nuosta- 
tų" [interaktyvus]. [žiūrèta 2012-10-

07]. <http://smm.lt/ti/docs/strategija2003-12.doc $>$.

Lietuvos Respublikos Vyriausybès nutarimas Nr. 339 „Dèl nacionalinès jaunimo verslumo ugdymo ir skatinimo 2008-2012 metų programos patvirtinimo" [interaktyvus]. 2008, Vilnius [žiūrèta 2013-10-31]. <http://www3.lrs.lt/ pls/inter3/dokpaieska.showdoc_l?p_ id=318306\&p_query=\&p_tr2=>.

Lydeka, Z. Verslininkas, verslumas ir verslininkystè. Organizaciju vadyba: sisteminiai tyrimai. (2). 1996.

Lydeka, Z. Verslumas ir verslininkystès sèkmè. Ekonomika. 2000, (52).

McGhee, P. The Academic Quality Handbook: Enhancing Higher Education in Universities and Further Education Colleges, Routledge Falmer, Taylor and Francis Group, London and New York, 2004. Studijų krypčiu skirtingoms pakopoms kūrimo metodika [interaktyvus]. [žiūrèta 2013-05-09]. <http:// www.skvc.lt/files/SKAR/Rezultatai/ metodika.pdf $>$.

Paulionienè, L. Verslumo ugdymas profesiniame mokyme. Profesinis rengimas: tyrimai ir realijos [interaktyvus]. 2007, 13 [žiūrèta 2013-11-28]. <http://esf. vdu.lt/esf/esf0013/downloads/16.pdf >.

Sodžiute, L. Verslumo ugdymas aukštojo mokslo sistemoje: taikomų meto- dų vertinimas bei Lietuvoje vykdomų verslumo projektų patirties apžvalga. Respublikinès mokslinès-praktinès konferencijos „Studijos besikeičiančioje verslo aplinkoje"pranešimu medžiaga. Alytaus kolegija, Lietuvos ekonomikos dèstytojų asociacija LEDA [interaktyvus]. Vilnius: Ciklonas, 2009 [žiūrèta 2013-11-03]. <http://leda.lt/studijos_ besikeiciancioje_verslo_aplinkoje.pdf\# page $=35>$.

Strazdiene், G.; Garalis, A. Verslumas: ugdymo programos ir jų efektyvumo raiška. Organizaciju vadyba: sisteminiai tyrimai [interaktyvus]. 2006 [žiūrèta 2013-11-28]. <http://archive.minfolit. lt/arch/5501/5651.pdf $>$.

Timmons, J.; Spinelli, S. New venture creation: Entrepreneurship for the 21st century. London: McGraw Hill, 2008.

Turner, C. Veskite $i$ sèkmę. Kaip sukurti verslias organizacijas. BMI: Baltos lankos, 2005.

Zakarevičius, P.; Župerka, A. Studentų verslumo ugdymas aukštosiose mokyklose. Organizaciju vadyba: sisteminiai tyrimai. 2011, 60.

Župerka, A. Studentų verslumo ugdymo plètrą Lietuvoje. Vadybos mokslas ir studijos - kaimo versly ir ju infrastruktūros plètrai. 2011, 2 (26).

\title{
ENTREPRENEURSHIP DEVELOPMENT POSSIBILITIES IN UNIVERSITY STUDIES
}

\author{
Živilè Labutè, Irena Žemaitaitytè \\ Mykolas Romeris University, Lithuania
}

Summary. The objective of the research: to show the possibilities of developing entrepreneurship in university studies. 
The objective of the research is to show the possibilities of developing entrepreneurship in university studies. Students of MRU, VU, VGTU and LEU participated in the research. Research methods were the following:

1. Theoretical - analysis of scientific literature, analysis of EU and Lithuanian documents regulating entrepreneurship, analysis of study curriculum and strategic plans in MRU, VU, VGTU and LEU;

2. Empirical research - questionnaires for students about possibilities of developing entrepreneurship at university;

3. Statistical method-descriptive statistics.

The results of the research. Having analyzed the data, the results showed that conceptions of entrepreneurship and its development do not differ in all 4 universities; they are the same in MRU,VU,VGTU and LEU. Students agree that it is a must to develop entrepreneurship in institutions of higher education but they do not know if such studies can be chosen in their curriculum. Also, they are not interested in the activities about developing entrepreneurship and have no idea if they are enterprising themselves. Students do not know if such a subject as developing entrepreneurship is present in their curriculum and if they can freely choose it themselves. Students would like to have developing entrepreneurship as a subject in their study curriculum which they would be able to choose freely by themselves.

The results of the research have shown that entrepreneurship is best developed in $M R U$ and VU. It is less developed in VGTU and the least developed in LEU.

Keywords: entrepreneurship, development of entrepreneurship, university studies.

Živilė Labutė, Mykolo Romerio universiteto Socialinių technologijų fakulteto edukologijos magistrè. Mokslinių tyrimų kryptys: edukologija, verslumo ugdymas.

Živilè Labutè, Mykolas Romeris University, Faculty of Social Technologies, Master Degree Student of Education Science. Research interests: education science, entrepreneurial education.

Irena Žemaitaitytė, Mykolo Romerio universiteto Socialinių technologijų fakulteto Edukologijos ir socialinio darbo instituto profesorè. Mokslinių tyrimų kryptys: suaugusiųjų švietimas, neformalusis suaugusiųjų švietimas, vyresnio amžiaus suaugusiųjų mokymasis, edukacinių technologijų taikymas ugdymo procese.

Irena Žemaitaityte், Mykolas Romeris University Faculty of Social Technologies, Institute of Education Science and Social Work, Professor. Research interests: adult education, nonformal education, education of elderly people, application of education technologies to the teaching process. 